\title{
Alicja Kicowska, Szkola rolnicza w Polsce w latach 1944-1989, Olsztyn 1998, Wydawnictwo ART w Olsztynie, ss.192
}

Podjęty w rozprawie temat znalazł już pewne odbicie $w$ dotychczasowej literaturze, zwłaszcza w opracowaniach Tadeusza Wieczorka $^{1}$, Stanisława Michalskiego ${ }^{2}$, czy też w wielu różnych publikacjach zbiorowych (w których autorami lub redaktorami byli również wymienieni badacze) ${ }^{3}$. Brakowało jednak studium, które podejmowałoby problematykę szkolnej edukacji rolniczej w wymiarze chronologicznym wskazanym $w$ pracy Alicji Kicowskiej i z uwzględnieniem najnowszych tendencji badawczych charakterystycznych dla polskiej humanistyki (w tym i nauk o wychowaniu) lat dziewięćdziesiątych.

W dotychczasowej literaturze wiele cennych walorów zachowuje nadal jej warstwa faktograficzna. Mniejsze dzisiaj znaczenie posiada natomiast jej warstwa eksplikatywna. Wiele zawartych w niej ustaleń i sądów wymaga obecnie weryfikacji, nowych wyjaśnień $i$ interpretacji. $Z$ tego punktu widzenia podjęcie przez Autorkę próby rekonstrukcji dziejów szkolnictwa rolniczego w przyjetych ramach chronologicznych, z podkreśleniem funkcji eksplikatywnej realizowanej $w$ związku z tym eksploracji naukowej, należy uznać za niezwykle cenne przedsięwzięcie.

Rozprawa A. Kicowskiej została oparta na solidnej podstawie źródlowej. Istotną część tej podstawy stanowią materiały archiwalne pochodzące m.in. $\mathrm{z}$ zasobów Archiwum Akt Nowych w Warszawie, Archiwum Zarządu Głównego Związku Nauczycielstwa Polskiego, Archiwum Ministerstwa Rolnictwa i Gospodarki Żywnościowej, Archiwum Państwowego w Olsztynie (szkoda, że Autorka nie wykorzystała materiałów archiwalnych znajdujących się również $w$ archiwach różnych innych ośrodków regionalnych), Akademii Rolniczo-Technicznej w Olsztynie, z zasobów archiwalnych wybranych szkół rolniczych. W szerokim zakresie zostały wykorzystane ponadto źródła druko- wane, także wspomnienia i relacje nauczycieli oraz absolwentów szkół rolniczych jak i literatura przedmiotu, dzięki której książka posiada także walory pracy syntetyzującej.

Rozprawa jest pracą o profilu historyczno-pedagogicznym. Podkreśla ten fakt takje Autorka, wskazując na niektóre, wypływające $\mathrm{z}$ tego charakteru pracy dyrektywy metodologiczne (s. 12, 14-16).

Podstawę konstrukcji pracy stanowi układ chronologiczno-problemowy. W konsekwencji strukturę książki uznać należy za dość klarowną i uzasadnioną. Można było jednak rozważyć kwestię połączenia dwóch pierwszych rozdzialów - w istocie o charakterze wprowadzającym - w ramach jednego, ilustrującego tradycje szkolnej edukacji rolniczej (do których nawiązywano, bądź też od których odżegnywano się w powojennej Polsce - do 1989 roku). Zasadne byłoby także wyodrębnienie i podkreślenie cezur wewnętrznych w rozważaniach dotyczących szkolnictwa rolniczego w latach 1961-1989 (w dotychczasowym podrozdziale V.2.). Omawiany tutaj okres blisku trzydziestu lat był przecież niejednorodnym tak pod względem lansowanej wtedy polityki rolnej, jak i szerzej rozumianej polityki oświatowej.

Praca Alicji Kicowskiej składa się z pięciu rozdziałów. W rozdziale pierwszym Autorka przedstawia narodziny i rozwój szkolnej edukacji rolniczej na ziemiach polskich do 1939 roku. Wskazuje m.in. na pierwsze w Polsce próby wprowadzania nauki rolnictwa do szkỏł (w dobie Komisji Edukacji Narodowej), tradycje i próby organizacji kształcenia rolniczego na poziomie wyższym, średniowyższym, średnim i niższym w XIX stuleciu i początkach XX wieku. Dyskusyjnym $w$ tej części pracy pozostaje przyjęty przez Autorkę zakres pojęcia zabór pruski (s. 28), obejmujący również tereny (Brzeg, Legnica), które pozostawały poza granicami Rzeczypospolitej od dawna i znalazły się 
ostatecznie pod panowaniem pruskim wcześniej od ziem wlączonych do Prus w wyniku rozbiorówPolski z końca wieku XVIII.

W rozdziale drugim Autorka podejmuje problemy szkolnictwa rolniczego $w$ okresie wojny i okupacji oraz prezentowane wówczas (w ramach różnych ośrodków polskiej konspiracji) wizje szkolnej edukacji rolniczej w dobie powojennej. Szkoda, że Autorka nie sygnalizuje szerzej w tym rozdziale losów szkolnictwa rolniczego na ziemiach polskich pod okupacją radziecką.

W rozdziale trzecim Alicja Kicowska prezentuje odbudowę i organizację szkolnictwa rolniczego $w$ nowych realiach politycznych, ekonomicznych i spolecznych lat 1944-1948 oraz dyskusję nad jego kształtem. Autorka nie poświęca jednak tutaj większej uwagi analizie realizowanych wówczas w szkołach rolniczych programów nauczania i stanu kadrowego tego szkolnictwa.

W rozdziale czwartym - chyba najbardziej wartościowym w całej pracy - Autorka podejmuje próbę przedstawienia przemian organizacyjno-programowych szkolnictwa roIniczego w świetle zamierzeń rządzącego obozu politycznego dotyczących tzw. kolektywizacji wsi i rolnictwa oraz jego dążeń do ideologizacji oświaty (w latach 1949-1956). Szkoła rolnicza - jak określano to już u progu tej swoistej wówczas ofensywy ideologicznej $w$ oświacie - miała uczestniczyć „w dziele przebudowy drobnej gospodarki rolnej na masowa, planową produkcje w gospodarce zespołowej... w dziedzinie wychowania ludzi zdolnych do realizacji wytkniętych zadań i celów przez plan 6-letni". Miała wychowywać „nowych ludzi, zdolnych do budowy socjalizmu, ludzi o naukowym poglądzie na świat, znających lepsze metody pracy i niezłomnie zmierzających do utrwalenia nowego badu społecznego...", „o nowej socjalistycznej moralności" (s. 113). W tej części pracy Autorka poświęca nieco uwagi również problematyce środowiskowej działalności szkoły rolniczej, która - niestety - ukierunkowana została na realizację ówczesnej wizji „socjalistycznych przemian wsi”.

W rozdziale piątym (obejmującym rozważania dotyczące ponad czterdziestu lat powo- jennej Polski) Autorka przedstawia zmiany strukturalno-programowe w szkolnictwie rolniczym po 1956 roku, jego rozwój i przekształcenia w latach 1961-1989 oraz funkcje (wewnętrzne i zewnętrzne) szkoły rolniczej w omawianym w tej części pracy okresie. Należy żalować, że $w$ zakresie tej ostatniej kwestii Autorka nie omawia szerzej również funkcji kompensacyjnej szkoły rolniczej (związanej z wyrównywaniem braków środowiskowych utrudniających uczniom kształcenie).

Odnosząc się do zawartości rozdziału piątego należałoby także powtórzyć uwage wyrażoną wcześniej przy prezentacji konstrukcji pracy.

Oceniając książkę A. Kicowskiej należy podkreślić profesjonalizm Autorki zarówno od strony warsztatowej, jak i merytorycznej. Cechująca te prace narracja jest poprawna pod względem logiczno-gramatycznym i teoretycznym. Narrację tę wyróżnia także jej instruktywny charakter. Praca A. Kicowskiej uwzgledniając ponadto rezultaty dotychczasowych badań nad szkolną edukacją rolniczą w powojennej Polsce (do 1989 roku), znacznie je rozszerza i wzbogaca, będąc jakby ich „krytyczną kontynuacja".

Lektura ksiazżki dr A. Kicowskiej potwierdza również opinię, którą wyraża też sama Autorka w Zakończeniu pracy, iż przemiany szkolnictwa rolniczego $w$ Polsce Ludowej były rezultatem „działań zewnętrznych”, że „decyzje o ich realizacji rodzily się poza społecznością pedagogów" (zatrudnionych w tych szkołach), wynikały $\mathrm{z}$ określonej polityki władz partyjnych i państwa wobec wsi i rolnictwa. Niemniej nie można jednak przekreślać w całości i jednoznacznie dorobku tego szkolnictwa w omawianym w pracy okresie (s. 178), nawet i wtedy, kiedy pamięta się, iż ok. $50 \%$ absolwentów szkół rolniczych nie podejmowalo pracy $w$ swoim zawodzie. Wielu absolwentów pracowało jednak $\mathrm{z}$ powodzeniem $w$ różnych sektorach rolnictwa (potwierdzaja to m.in. zaprezentowane na początku lat dziewięćdziesiątych wyniki badań $T$. Wieczorka nad przydatnością zawodową absolwentów techników rolniczych). Szkoła rolnicza będąc często miejscem kształ- 
cenia także i dla tej młodzieży, która nie łączyla edukacji rolniczej z zamiarem podjecia pracy $w$ zawodzie rolnika, posiadając niejednokrotnie wyjątkowy klimat spoleczno-wychowawczy, charakterystyczny dla tradycji polskiego szkolnictwa rolniczego, stwarzala tej młodzieży możliwości zaspokojenia jej podstawowych potrzeb wynikających zarówno $\mathrm{z}$ indywidualnego, jak $\mathrm{i}$ społecznego rozwoju.

Zatrzymując się jeszcze nad merytoryczną stroną rozprawy należy zauważyć brak (w odniesieniu do wszystkich wyodrebnionych w pracy okresów) szerszych i może bardziej wnikliwych rozważań Autorki nad problematyką kwalifikacji kadry pedagogicznej (także w zakresie nauczania przedmiotów zawodowych), bazy materialnej szkół ich całego zaplecza dydaktycznego (zwłaszcza programów, podręczników), realizacji procesu kształcenia teoretycznego i praktycznego. Te przecież elementy - jak można sądzić - decydowały i nadal przesądzają 0 jakości szkolnej edukacji rolniczej. Autorka nie poświęciła także uwagi tzw. „geografii szkół rolniczych" i nie ukazała dysproporcji regionalnych $w$ rozwoju szkolnej edukacji rolniczej. Interesująca i cenna bylaby również prezentacja problemów związanych tak $\mathrm{z}$ funkcjonowaniem i dorobkiem całego "zaplecza teoretycznego" działalności pedagogicznej szkół rolniczych (różnych ośrodków naukowo-badawczych podejmujących problematyke szkolnej edukacji rolniczej, w szczególności: roli społecznej i kwalifikacji kadry nauczającej, przesłanek organizacyjnych i dydaktyczno-wychowawczych działalności szkół rolniczych oraz szeroko rozumianej roli szkoły rolniczej $w$ procesie społeczno-agramych i kulturowych przeobrażeń środowisk wiejskich, w tym i w procesie profesjonalizacji pracy rolnika), jak i z pracą badawczą oraz pedagogiczną działalnością innowacyjną nauczycieli tych szkół. Autorka ustalając przedmiotowy zakres pracy wiele tych problemów pominęła świadomie, uważając - po części słusznie - iż niektóre $\mathrm{z}$ nich zostały już podjęte w dotychczasowej historiografii, albo też, że wymagajaz one osobnych i dalszych badań.
Autorka nie przywiązuje także większego znaczenia do różnych form wzbogacających dokumentacyjna stronę pracy. Brakuje $w$ niej załączników ważnych dla omawianej problematyki, a zwłaszcza tabel ilustrujących aspekt ilościowy rozpatrywanych w pracy zagadnień. Krytyczne uwagi może budzić także stosowana w pracy podwójna redakcja przypisów ukazujących źródła i literaturę przedmiotu. Sądzić można, że dla pracy o profilu historyczno-pedagogicznym oraz o takim zakresie chronologicznym i problemowym korzystniejsza bylaby jednolita, „tradycyjna” redakcja przypisów, zawierająca ciągłą numerację w ramach poszczególnych partii opracowania i pełen opis bibliograficzny wykorzystywanych prac i źródeł (charakteryzująca więlkszość publikacji tego typu). Zastosowany w książce sposób odsyłania do literatury i źródeł został jednak narzucony Autorce przez Wydawnictwo.

Zaprezentowane $w$ recenzji uwagi krytyczne, z których większość posiada charakter dyskusyjny, nie podważaja wyrażonej wcześniej ogólnej opiniii na temat książki A. Kicowskiej. $\mathbf{Z}$ całą pewnością można tę publikację zarekomendować nie tylko $w$ gronie historyków wychowania i badczy dziejów oświaty rolniczej lecz także w szerszym środowisku badaczy i praktyków edukacji interesujących się problematyką dziejów oświaty $w$ powojennej Polsce $w$ szerokim społeczno-ekonomicznym i politycznym kontekście.

\section{Wieslaw Jamrożek}

1 Zob. m.in.: T. Wieczorek, Historia szkolnictwa rolniczego w Polsce, Warszawa 1980; T. Wieczorek, Tendencje rozwojowe szkolnictwa rolniczego $w$ Polsce (1944-1990), Warszawa 1990.

${ }^{2}$ Zob. m.in.: S. Michalski, Drogi rozwojowe ksztalcenia rolniczego na poziomie niższym $i$ średnim w Polsce Ludowej, „Kwartalnik Pedagogiczny” 1966, nI 2; S. Michalski, Szkola rolnicza w srodowisku, Warszawa 1979.

${ }^{3}$ Rozwój oswiaty rolniczej w Polsce Ludowej, praca zbior. pod red. T. Wieczorka, Warszawa 1967. 